\title{
Rural Small and Medium Enterprise: Information and Communication Technology as Panacea
}

\author{
Obadun Mathew Olukayode ${ }^{1}$, Wan Rozaini Sheik Osman ${ }^{2}$, Husam \\ Abdulhameed Hussein ${ }^{3}$, Ahmed Naser Ismael ${ }^{4}$, Ahmed Abdulla Masoud ${ }^{5}$, \\ Abdul Ghafar Mansor ${ }^{6}$ \\ 1, 2, 3, 4, 5, 6 (School of Computing, Universiti Utara Malaysia, Malaysia)
}

\begin{abstract}
Though, there are variations in the definitions of small and medium enterprises but it can be generally accepted as business activities that employ the services of 150 or fewer people in its activities and attributed with no link to the public limited company. Among the challenges facing the prospect of small and medium enterprise in the rural areas is the lack of integrating information and communication technology skills or strategies into their practice. Therefore, this paper engages the exploration of previous literatures in finding the benefits of information and communication technology to the rural small and medium enterprise.
\end{abstract}

Keywords: ICT, Rural Areas, Rural SME, Small and Medium Enterprise

\section{Introduction}

Small and medium enterprise (SME) is defined and described as a business that engage the services of 150 or fewer people in its activities and possesses no integration with public limited company (Southern \& Tilley, 2000; Modimogale \& Kroeze, 2011). Knowing to the populace, entrepreneur has been accepted worldwide and getting increment on a daily basis as a result of the contribution it brings to the humanity and environments. Meanwhile, entrepreneur has been identifying as one of the contributors of $20 \%$ to $50 \%$ of complete employment, while $30 \%$ to $50 \%$ development have been recorded in the rural areas (Okpara and Wynn, 2007). This explains that importance of entrepreneur in the society, especially in the rural areas cannot be overemphasised as it has been marked as societal developing mechanism. Though, SME may be meant and addressed different issues among different people, but is has been recognised as a catalyst for developing and promoting rural communities (Okpara and Wynn, 2007; Taylor and Murphy, 2004; Martin and Matlay, 2001).

Despite the numerous benefits of SME in the rural communities, there is challenge of promoting their output to the outside world due to their localisation of operation. Many of the SME practitioners lack modern day information and architectures to propel their businesses for the future use (Mutula \& Van-Brakel, 2006). Having incorporating information and communication technology (ICT) into the practising of SME in the rural areas would definitely assist entrepreneurial development by smoothing their act of job creations, innovations industrial and nation building (Akande and Ojukuku, 2008; Darren and Conrad, 2009). Pursuing this further, previous studies have argued that integration of ICT (broadband) to the rural SME activities would reduce the operation tasks of SME and assists in employment generations (Ishola, Wan, \& Azizah, 2013).

Furthermore, ICT is known as a powerful tool that helps organizations to participate in both local and international markets through promoting accountability, improving the service delivery and enhancing opportunity's development (Schwalbe, 2006). Almost all the countries in the emerging world have increased the ways of investing in ICT in order to improve the output of the organisation. Moreover, there is need for essential mechanism to ensure that ICT investments and operations are acceptable, effective and efficient in the rural areas for business purposes. Besides, ICT is designed as enabler in SME businesses and leads to achieving competitive advantage especially in rural SMEs from their ICT. Indeed, alignment of ICT application on SME helps organisations to achieve instant objectives of their business goals.

\section{Overview Of Small And Medium Enterprise}

The SME is the driving force behind a large number of innovations which contributes to the growth of the national economy through employment creation, investments and exports (Milford, 2000). Thus, there is running high global interest in the SME especially, interest is running high globally particularly in developing countries that are in the slow pace in overriding the economic and developmental gaps. The study of Rowen (1999) revealed that Chinese and foreign experts estimate that SME is responsible for about $60 \%$ of China's industrial output and employ about $75 \%$ of the workforce in China's cities and towns. Hence, SME creates jobs for workers who have been laid off from state-owned enterprises due to the steady transition from communism to a market based economy. 
In addition, interest in the role of SME in the development process continues to be prime policy debates in developing countries due to its relevance in the region (Cook and Nisxon, 2000). In other words, the importance of the SME in the economy has lured the government of Taiwan to inject $\$ 61$ million towards branding initiative, designed to assist SMEs in developing their own brand. This was initiated with the full consciousness of the ability of SMEs to drive the economy particularly in the medium term. Moreover, SME is often referred to as the engine of growth and catalysts for socio-economic transformation of any nation (Cook and Nisxon, 2000; Elumilade et al., 2006). Therefore, it could be encircled as the vehicle towards achieving national economic objectives of employment generation, poverty reduction at low investment cost and the development of entrepreneurial capabilities. Besides, other benefits of SME include access to the infrastructural facilities, stimulation of economic activities (suppliers of various items and distributive trades for the produced items), stemming from rural urban migration, enhancement of standard of living of the employees of the SMEs and their dependents (Cook and Nisxon, 2000; Elumilade et al., 2006).

\section{Small And Medium Enterprises In The Rural Areas}

Despite the success of the SME in some parts of the world, the studies have shown that SME in the rural areas is still suffering some headway (Elumilade et al., 2006; Cook and Nisxon, 2000). In other words, the SME in the rural areas of the developing countries are receiving slow support and modern infrastructure form the government while practising their activities. Indeed, SME in the rural areas lacks effective organisation and knowledge of modern management techniques. The fact that SME produces fast operation and quick returns in businesses, it should remain a veritable tool for encouragement of entrepreneurship, creating immediate employment opportunities, promoting regional trade, breaking monopoly of larger enterprises and poverty alleviation (Cook and Nisxon, 2000). Moreover, many of SME in the rural part of the continent of Africa are better but fail to justify the present standard in the area of micro businesses due to the massive corruption (Mambula, 2002).

\section{Characteristics Of Small And Medium Enterprises In The Rural Areas}

A major characteristic of SME in the rural areas is basically focusing on the capacity of the structures of owners basically family. This explains that SME is dominance on the sole proprietorships or partnerships (Simpson \& Padmore, 2006). Therefore, the true ownership's structure of SME is one-man, family or partnership business. Other features of rural SME are as follows:

i. Low access to long term funds.

ii. Exorbitant cost of funds due to the high interest rates and bank charges.

iii. Poor economies of scale benefits.

iv. Poor managerial skills due to their inability to pay for skilled labour.

v. Poor product quality output.

vi. Poor management of financial resources and inability to distinguish between personal and business finance.

vii. High production costs due to inadequate infrastructure and wastages.

viii. Absence of Research and Development.

ix. Little or no training and development for their staff.

x. Poor documentations of policy, strategy, financials, plans, information and systems.

xi. Low entrepreneurial skills, inadequate educational or technical background.

xii. $\quad$ Lack of adequate financial record keeping.

xiii. Low capitalisation.

xiv. Lack of efficient technology especially for the processing, preservation and storage.

$x v$. Lack of access to international market.

xvi. Lack of succession plan.

xvii. Poor access to vital information.

\section{Information Communication Technology And Sme In The Rural Areas}

For some times now, ICT has been integrated with small businesses showing that it is not a luxury but necessity (American Marketing Association, 2006). Therefore, small business has taken the steps to accept the ICT as tool to triumph in their operations especially in the remote and rural areas. Meanwhile, many authors have stressed that it is no longer new to see computers in small shops and offices while transacting businesses in some countries (Darren and Conrad, 2009). Generally, small businesses in the remote areas and cities have inculcated the habit of investing on business centres, focusing activities like typing, photocopy, lamination and phone call centres (Reynolds, 2002). The study of Elumilade et al. (2006) argued that the influence of ICT on some businesses and offices has been increasing exponentially. This shows that for it would be difficult for the companies and small businesses to compete in the present world. Going by this, ICT has been tagged as tool that 
revolutionises the small business due to its ability to facilitate business promotion, efficiency and growth. Indeed, business roles like ordering, transaction, delivery, inventory control and accounting could be smoothed irrespective of the locations through the high speed internet known as broadband (Ishola et al., 2013a; Gilmore et al., 2001).

Furthermore, the impact of mobile telephony technology has been recorded positive effect on the small businesses positively (Gilmore et al., 2001). In some places in the African continent, mobile market has been the fastest growing in the world in the previous years and has double the Global market (Ariyo, 2008). For instance, the introduction of mobile phones in Nigeria earlier in the 2000s, small business which operate as call centres have been on the increase and continue to grow in many folds (Elumilade et al., 2006). The development of mobile telecommunication industries has brought about opportunities for operators in informal businesses for the users who could not afford fixed line telephones, fax and internet. It has been previously argued that ICT has improved from its known back office role towards a strategic role which supports new business strategies (Lopez-Nicolas \& Soto-Acosta, 2010; Henderson \& Venkatraman, 1999). Researchers like Raymonds and Blili (1997), Poon and Swatman (1999) proposed ICT strategies based on experiences derived from large firms and injected it into the SME for competitive advantages while competing in the global market. Indeed, the use of ICT in facilitating the activities of SME could be achieved through the internet applications (Ishola et al., 2013b; Lopez-Nicolas \& Soto-Acosta, 2010).

\section{Conclusion}

This paper has addressed the issues confronting SME in the context of rural and remote areas especially in the developing countries. One of the challenges preventing the rural SME to compete with outside world is the slow support and modern infrastructure while practising their activities The paper explored the previous literatures and presented that SME is the driving force which is a large number of innovations that contributes to the growth of the national economy through employment creation, investments and exports. Besides that, the paper highlighted characteristics of rural SME as Lack of efficient technology especially for the processing, preservation and storage, Lack of access to international market, Lack of succession plan, Poor access to vital information and many more. Consequently, ICT is recommended as the link to the rural SME's success and as the panacea for the current issues confronting the success of SME in the rural areas.

\section{Reference}

[1]. American Marketing Association (2006). Marketing Terms Dictionary. Retrieved from www.marketing power.com/index, May $10^{\text {th }}, 2014$.

[2]. Ariyo, D. (2008 ). Small firms are the backbone of the Nigerian economy. Africa Economic Analysis, Retrieved from www.africaeconomicanalysis.org/articles/gen/smallhtm.html, May $14^{\text {th }}, 2014$.

[3]. Cook, P., \& Nixson, F. (2000). Finance and Small and Medium-Sized Enterprise Development.

[4]. Darren, L., \& Conrad, L. (2009). Entrepreneurship and Small Business management in the Hospitality Industry. Jordan Hill, UK: Elsevier Linacre House.

[5]. Elumilade, D.O., Asaolu, T.O., \& Adereti, S.A. (2006). Appraising the Institutional Framework for Poverty Alleviation Programmes in Nigeria. International Research Journal of Finance and Economics, Vol. 3, pp. 66-77.

[6]. Gilmore, A., Carson, D., \& Grant, K. (2001). SME Marketing in Practice. Marketing Intelligence \& Planning, Vol. 19, No. 1, pp. 611.

[7]. Henderson, J., \&Venkatraman, N. (1999). Strategic alignment: leveraging transforming

[8]. Ishola, D.M., Wan, R.S.O., \& Azizah, A. (2013). Investigating the Readiness of Broadband Continuous Usage among Rural Dwellers in the Northern Region of Malaysia. International Journal of Computer and Communication Engineering, Vol. 2, No. 6, pp. 679-683.

[9]. Ishola, D.M., Wan, R.S.O., \& Azizah, A. (2013a). Investigating the Readiness of Broadband Continuous Usage among Rural Dwellers in the Northern Region of Malaysia. International Journal of Computer and Communication Engineering, Vol. 2, No. 6, pp. 679-683.

[10]. Ishola, D.M., Wan, R.S.O., \& Azizah, A. (2013b). Efficacy of UTAUT Model in Continuation of Usage of Broadband in the Rural Areas of Northern Region of Malaysia. Proceedings of International Conference on Rural ICT Development, pp. 174 - 179.

[11]. Lopez-Nicolas, C., \& Soto-Acosta, P. (2010). Analyzing ICT Adoption and Use Effects on Knowledge Creation: An Empirical Investigation in SMEs. International Journal of Information Management, Vol. 30, pp. 521-528.

[12]. Mambula, C. (2002). Perceptions of SME Growth Constraints in Nigeria. Global Perspective, Vol. 40, No. 1, pp. 58-65.

[13]. Martin, L. M., \& Matlay, H. (2001). "Blanket" Approaches to Promoting ICT in Small Firms: Some Lessons from the DTI Ladder Adoption Model in the UK. Internet Research: Electronic Networking Application and Policy, Vol. 11, No. 5, pp. 399-410.

[14]. Milford, B. (2000). Small Enterprise Development in the Yugoslav Successor States. Moct-Most. Vol. 2, pp. 171-206.

[15]. Modimogale, L., \& Kroeze, J.H. (2011). The Role of ICT within Small and Medium Enterprises in Gauteng. Communications of the IBIMA, pp. 1-13

[16]. Mutula, S., \& Van-Brakel, P. (2006). Ereadiness of SMEs in the ICT Sector in Botswana with Respect to Information Access. The Electronic Library, Vol. 24, No. 3, pp. 402-417.

[17]. Okpara, J. O., \& Wynn, P. (2007). Determinants of Small Business Growth Constraints in a Sub-Saharan African Economy. SAM Advanced Management Journal, Vol 12, pp. 23-31.

[18]. Organizations. IBM Systems Journal, Vol. 31, No. 1, pp. 472-484.

[19]. Poon, S., \& Swatman, P. (1999). An Exploratory Study of Small Business Internet Commerce. Information \& Management, Vol. 35, No. 1, pp. 9-18.

[20]. Raymonds, L., \& Blili, S. (1997). Adopting EDI in a Network Enterprise: the Case of 
[21]. Reynolds, P.L. (2002). The Need for a New Paradigm for Small Business Marketing: What Was Wrong with the Old One? Journal of Research in Marketing \& Entrepreneurship, Vol. 4, No. 3, pp. 191-205.

[22]. Rowen, H. S. (1998). Behind East Asian Growth: The Political and Social Foundations of Prosperity. Routledge, London.

[23]. Schwalbe, K. (2006). Information Technology Project Management. Boston, MA: Thomson Course Technology.

[24]. Simpson, M., \& Padmore, J. (2006). Marketing in Small and Medium Sized Enterprises. International Journal of Entrepreneurial Behaviour \& Research, Vol. 12, No. 6, pp. 361-387.

[25]. Southern, A., \& Tilley, F. (2000). Small Firms and Information and Communication Technologies (ICTs): Toward a Typology of ICTs Usage. New Technology, Work and Employment, Vol. 15, No. 2, pp. 138-154.

[26]. Subcontracting SMEs. European Journal of Purchasing \&Supply Management, Vol. 3, No. 3, pp. $165-175$.

[27]. Taylor, M., \& Murphy, A. (2004). SMEs and E-Business. Journal of Small Business and Enterprise Development, Vol. 11, No. 3, pp. 280-289. 